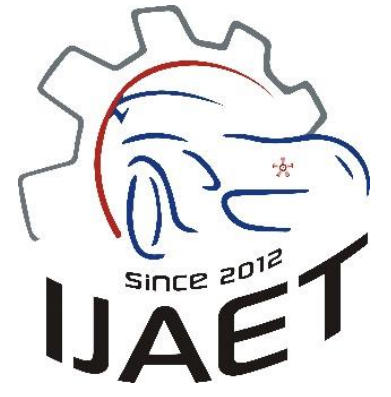

e-ISSN: 2146 - 9067

International Journal of Automotive

Engineering and Technologies

journal homepage:

https://dergipark.org.tr/en/pub/ijaet

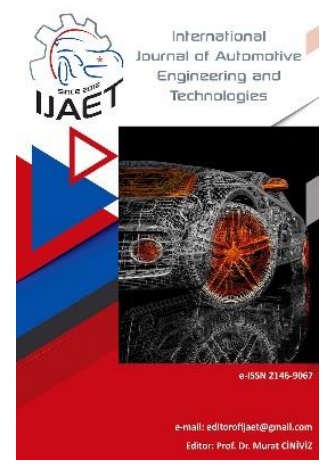

Original Research Article

\title{
Investigation of the effects of camelina sativa biodiesel and eurodiesel blends on vehicle performance and emissions
}

\author{
M. Mahmut Yildiz ${ }^{1}$ and A. Engin Özçelik ${ }^{2, *}$ \\ ${ }^{1}$ Selcuk University, Institute of Science, Konya/Turkey. \\ 2 , * Selcuk University, Faculty of Technology, Konya/Turkey.
}

\section{ARTICLE INFO}

1. 0000-0002-1999-0353

2. $0000-0002-8646-0950$

Doi: 10.18245 / ijaet. 858795

* Corresponding author eozcelik@ selcuk.edu.tr

Received: Jan 12, 2021

Accepted: Feb 27, 2021

Published: Mar 31, 2021

Published by Editorial Board Members of IJAET

(C) This article is distributed by Turk Journal Park System under the CC 4.0 terms and conditions.

\begin{abstract}
Studies have been conducted on improving engine performance, reducing environmental pollution caused by vehicles, and using alternative fuels. In the study, tests are carried out in a laboratory environment to check whether the engine has reached the intended use. Testing of internal combustion engines is crucial to research and teaching, trade and environmental pollution. Depending on the purpose of the test, the type and duration of vehicle tests will vary. Automobile manufacturing companies and research units will conduct a series of scientific and long-term tests in the vehicle development process. Thanks to engine and vehicle tests under different operating conditions, the measured values such as economy, power, moment, emission are compared with performance curves.

In this study, biodiesel was obtained from crude camelina sativa oil using the transesterification method. Camelina sativa biodiesel was mixed with Eurodiesel at the rate of $7 \%\left(\mathrm{~B}_{7}\right), 20 \%\left(\mathrm{~B}_{20}\right)$ and $50 \%\left(\mathrm{~B}_{50}\right)$. Vehicle performance measurements of biodiesel-Eurodiesel blends were made on a vehicle with fourstroke, four-cylinder, Common-rail fuel system, turbocharged and water-cooled engine using a chassis dynamometer. Vehicle performance and exhaust emissions were measured at different speeds during the vehicle chassis dynamometer test. While the highest moment value was obtained at $80 \mathrm{~km} / \mathrm{h}$ in $\mathrm{B}_{7}$ fuel, the maximum engine power was obtained in $\mathrm{B}_{7}$ fuel at $160 \mathrm{~km} / \mathrm{h}$.

Average engine power and maximum engine torque of B100 fuel decreased by $3,28 \%$ and 10,21\% compared to Eurodiesel fuel. As the rate of biodiesel increased, specific fuel consumption increased. The highest specific fuel consumption was obtained with $91,6 \mathrm{~g} / \mathrm{kWh}$ in B100 fuel at $160 \mathrm{~km} / \mathrm{h}$. The average specific fuel consumption of B100 fuel increased 38,5\% compared to Eurodiesel fuel.

When we look at the results of exhaust emission measurements, it is seen that camelina sativa biodiesel and fuel mixture decreased $\mathrm{CO}, \mathrm{CO}_{2}$ and $\mathrm{HC}$ values compared to Eurodiesel fuel, but increased $\mathrm{NO}_{\mathrm{x}}$ values.

Keywords: Biofuel, Chassis Dynamometer, Engine Performance, Emission, Camelina Sativa
\end{abstract}

\section{Introduction}

According to the recent increase in oil consumption, many concerns have arisen about the future of fuel, which is the main energy source. Until now, energy demands have been met with the use of fossil resources that led to 
the depletion of these reserves. In addition to the depletion of these reserves, adverse environmental impacts such as global warming, ozone depletion and deforestation have led to the urgent need to use alternative energy that will be economically efficient, environmentally friendly and socially equitable [1]. Due to the steady increase in fuel demand and the increasing number of vehicles and people today, these expectations may remain unchanged for decades to come. Prices of fossil fuels are expected to rise as the demand for fossil fuels increases significantly and resources are beginning to run out. As a result, the expected scarcity of fossil fuels and the negative environmental impacts from the use of fossil fuels have led to research on renewable transport biofuels [2-5].

Studies have been conducted on improving engine performance, reducing environmental pollution caused by vehicles, and using alternative fuels. In the study, tests are carried out in a laboratory environment to check whether the engine has reached the intended use. Testing of internal combustion engines is crucial to research and teaching, trade and environmental pollution [6]. Depending on the purpose of the test, the type and duration of vehicle tests will vary. Automobile manufacturing companies and research units will conduct a series of scientific and long-term tests in the vehicle development process. These tests can often be performed on newly developed engines. During the manufacturing phase, the engine and vehicles are tested at the end of the assembly line. These tests are extremely important in terms of controlling the production. Similar tests are performed on the newly developed engine and vehicle and it is investigated whether the results reach satisfactory values. In addition, some engine tests have been carried out to determine the quality of fuel and engine oil and these test are used for educational purposes. Test results are the basis for the design and manufacture of the engine and experiments are carried out to check whether the engine provides the required power. Engine power and economy under different operating conditions are evaluated through engine specifications (i.e. performance curves). Thanks to engine and vehicle tests, the measured values such as economy, power, moment, emission are compared with performance curves [7-9].

The unbalanced distribution of fossil fuels, which make up the largest part of primary energy resources, has caused some disadvantageous countries to become dependent on advantageous countries. This dependency is increasing day by day as the demand for energy increases. For this reason, countries are now looking for ways to utilize their energy resources, reduce dependence on foreign countries, and diversify their energy resources to ensure supply and demand security [10-12].

The nature produces 150 billion tons of biomass annually and only $10 \%$ of this biomass is used for commercial purposes. Now, the world is trying to stimulate this great potential, and biomass technology is rising significantly. While biofuels have become vital in providing energy supply and dealing with global warming, they have become the focus of attention of people around the world and measures for future generations are increased [13]. Environmental awareness is directly related to the economic and welfare levels of the countries. Therefore, the amount of harmful substances in the exhaust emissions of economically developed countries is determined by the standards. Today, LPG injection system has been developed in parallel with the gasoline injection system [15].

Biodiesel is the fuel used instead of Eurodiesel. It is a fuel that is formed as a result of the reaction with methanol (short-chain alcohol) by adding catalysts to vegetable oil or animal oils obtained from oil plants such as canola, sunflower, corn, cotton, camellia. Waste frying oils and oils of animal origin can also be used as raw materials for biodiesel [15].

Biodiesel does not contain petroleum products, but can be used as biodiesel or mixed with various proportions of Eurodiesel (Diesel). Unadulterated biodiesel and Eurodieselbiodiesel blends are replaced in a Euroiesel engine with elements that won't be corroded by biodiesel and they become useful. Biodiesel is named as $\mathrm{B}_{7}$ : $93 \%$ Eurodiesel - 7\% biodiesel $\mathrm{B}_{20}, \mathrm{~B}_{50}, \mathrm{~B}_{100}$ according to its mixture with Eurodiesel. The most suitable $\mathrm{B}_{20}$ mixture is considered to have commercial value, as these ratios affect the environment, economy, exhaust emissions and fuel properties [16-19].

This study was carried out to determine the 
engine performances and exhaust emission values of Eurodiesel and camelina sativa biodiesel in different blends and different vehicle speeds with a vehicle dynamometer and to compare these values with the Eurodiesel fuel of a vehicle with Eurodiesel fuel system.

\section{Material and Method}

In this study, Selçuk University Technology Faculty, Mechanical Engineering Biofuel Laboratory was used to produce biodiesel from camelina sativa oil. Camelina sativa biodiesel obtained from camelina sativa oil was used in the 2012 Toyota brand Verso 2.0 type vehicle with $2000 \mathrm{cc}$ turbo-charged Common-rail Eurodiesel fuel system at Selçuk University, Faculty of Technology Automotive Department. The technical characteristics of the engine belonging to this vehicle are given in Table 1 .

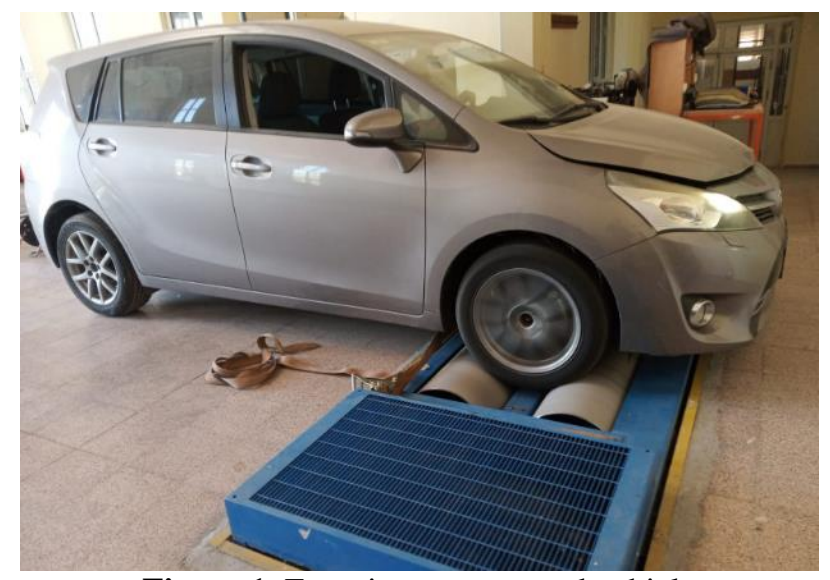

Figure 1. Experiment setup and vehicle

Table 1. Technical characteristics of the test vehicle [20]

\begin{tabular}{lc}
\hline \multicolumn{1}{c}{ Specisifications } & Descriptions \\
\hline Brand & Toyota \\
Model & Verso 2.0 \\
Drive shape & Front wheel drive \\
Year of manufacture & 2012 \\
Wheelbase & 2780 \\
Vehicle length / Width / & $4440 / 1790 / 1620$ \\
height (mm) & \\
Maximum vehicle weight & 1540 \\
(kg) & \\
Vehicle & \\
characteristics & \\
Number of cylinders & 4 \\
Diameter x stroke (mm) & $86 x 86$ \\
Engine volume $\left(\mathrm{cm}{ }^{3}\right)$ & 2000 \\
Number of valves & 16 \\
Compression ratio & $15: 8$ \\
Fuel system & $92.46-3600$ \\
Maximum power $(\mathrm{kW}-\mathrm{d} / \mathrm{d})$ & $300-2400$ \\
Maximum torque $(\mathrm{Nm}-\mathrm{d} / \mathrm{d})$ & \\
Emission standards & 143 ( Euro 5) \\
$\mathrm{CO}_{2}$ Emissions $(\mathrm{g} / \mathrm{km})$ & \\
\hline
\end{tabular}

While preparing Eurodiesel fuel blends and camelina oil methyl ester, 93\%, 80\%, 50\% and $0 \%$ Eurodiesel was added and then $7 \%, 20 \%$, $50 \%$ and $100 \%$ biodiesel mixture was obtained respectively, which will provide the mixture by volumetrically. To determine the viscosity, density, thermal value and flash point values of the $\mathrm{B}_{7}, \mathrm{~B}_{20}, \mathrm{~B}_{50}, \mathrm{~B}_{100}$ and Eurodiesel fuel obtained from the mixtures, the measurements were made in the Biodiesel Laboratory of Agricultural Machinery Department at Selçuk University, Agricultural Faculty. The experimental setup is given in Figure 1 below.

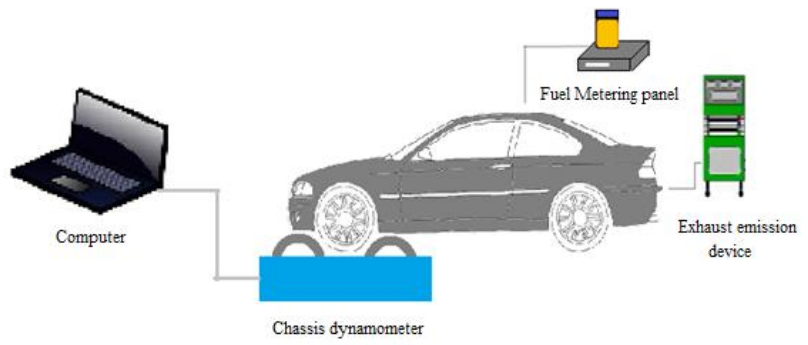

Figure 1. Experimental test setup

In the experiments, the HPT 6100 brand chassis dynamometer was used. The vehicle dynamometer can perform road test, power test and speed test [21]. The technical information of the Chassis Dynamometer device to be used in the experiments is given in Table 2. Properties of camelina biodiesel and test method types are given in Table 3.

Table 2. Technical characteristics of the chassis dynamometer [22]

\begin{tabular}{lll}
\hline Specisifications & Unit & Descriptions \\
\hline Brand & & $\mathrm{HPT}$ \\
Model & & 6100 \\
Drum Diameter & $\mathrm{m}$ & 1,2 \\
Max Speed & $\mathrm{km} / \mathrm{h}$ & 200 \\
Maximum axle load & $\mathrm{kN}$ & 35 \\
Capacity & $\mathrm{kW}$ & 170 \\
\hline
\end{tabular}

\subsection{Biodiesel production from camelina oil}

Although biodiesel is produced by various methods, the most widely used method today is the transesterification method. This method; It is the process of re-esterifying vegetable oil by reacting a catalyst with alcohol. This method is the most effective method in reducing viscosity today [24]. Biodiesel production; It consists of 6 stages: mixing alcohol and catalyst, reaction, separation, washing, drying and storage [25].

The following items have been made in the production of biodiesel;

- Heating was made up to $60^{\circ} \mathrm{C}$ by mixing the oil in the reactor. 
Table 3. Properties of B100 camelina biodiesel [23].

\begin{tabular}{llccl}
\hline Specifications & Unit & EN 14214:2010 & Camelina biodiesel & Test method \\
\hline Density $15^{\circ} \mathrm{C}$ & $\mathrm{kg} / \mathrm{m}^{3}$ & $860-900$ & $885-888$ & EN ISO 12185 \\
Kinematic viscosity $\left(40{ }^{\circ} \mathrm{C}\right)$ & $\mathrm{mm}^{2} / \mathrm{s}$ & $3,5-5$ & $4,53-5,45$ & EN ISO 3104 \\
Cold filter plugging point & ${ }^{\circ} \mathrm{C}$ & - & -3 & EN 116 \\
Cloud point & ${ }^{\circ} \mathrm{C}$ & - & 3 & ASTM D 2500 \\
Methyl ester content & $(\mathrm{wt} \%)$ & 96,5 & 97,5 & EN 14103 \\
Flash Point & ${ }^{\circ} \mathrm{C}$ & 101 & 202 & EN ISO 3679 \\
Sulfur content & $\mathrm{mg} / \mathrm{kg}$ & 10 & 0,59 & EN ISO 20846 \\
Carbon residue & $\mathrm{wt} . \%$ & 0,3 & 0,019 & EN ISO 10370 \\
Water content & $\mathrm{mg} / \mathrm{kg}$ & 500 & 120 & EN ISO 12937 \\
Copper corrosion test $\left(3 \mathrm{~h}, 50^{\circ} \mathrm{C}\right)$ & & 1 & $1 \mathrm{~A}$ & EN ISO 2160 \\
Oxidation stability $\left(110{ }^{\circ} \mathrm{C}\right)$ & $\mathrm{h}$ & 6 & $1,3-2,2$ & EN 14112 \\
Acid value & $\mathrm{mg} \mathrm{KOH} / \mathrm{g}$ & 0,5 & 0,36 & EN 14214 \\
Iodine number & $\mathrm{g} . \mathrm{I} / \mathrm{g}$ & 120 & 154 & EN 14111 \\
Thermal Value & $(\mathrm{MJ} / \mathrm{kg})$ & - & 36,81 & EN 50082 \\
\hline
\end{tabular}

Table 3. Measured values in Eurodiesel and biodiesel blends

\begin{tabular}{lcccccc}
\hline Biodiesel & B7 & B20 & B50 & B100 & Eurodiesel & Standard \\
\hline Density & 834 & 845,9 & 865,6 & 884,8 & 824,9 & EN ISO 12185 \\
Flash Point $\left({ }^{\mathbf{o}} \mathbf{C}\right)$ & 164 & 175 & 186 & 205 & 65 & EN ISO 3679 \\
Kinematic viscosity $\left(\mathbf{4 0}^{\mathbf{0}} \mathbf{C}\right) \mathbf{~ m m}^{2} / \mathbf{s}$ & 2,832 & 3,18 & 4,25 & 5,16 & 2,82 & EN ISO 3104 \\
Thermal Value $(\mathbf{M J} / \mathbf{k g})$ & 37,57 & 37,42 & 37,09 & 36,81 & 47,14 & EN 50082 \\
\hline
\end{tabular}

- $\quad 20 \%$ methanol by volume of camelina oil and 3,5 g NaOH catalyst per liter oil were added and the reaction was carried out in two stages.

- In the reaction, firstly, methanol and $\mathrm{NaOH}$ catalyst were mixed and the methoxide solution was obtained and mixed by pouring into the camelina oil in the reactor. Mixing was done at $80 \mathrm{l} / \mathrm{min}$ for sixty minutes. At the end of mixing, the glycerin accumulated at the bottom of the mixture that was kept for at least two hours was removed.

- When the raw biodiesel in the reactor was kept for 1 day to cool down and the glycerin contained in it to settle to the bottom, the glycerin accumulated at the bottom was taken again.

- $\quad$ Pure biodiesel and distilled water at a temperature of $50{ }^{\circ} \mathrm{C}$ were mixed equally by volume, washed and left to rest for twelve hours to precipitate the water. At the end of the washing process, the unreacted fatty acids, alcohol, $\mathrm{Na}+$ ions, catalysts and glycerin that could be in the structure of the biodiesel were removed.

After discharging the water accumulated at the bottom of the reactor, the water remaining in the biodiesel is heated and mixed at $100{ }^{\circ} \mathrm{C}$ for at least two hours, after which the desired biodiesel is obtained after evaporation. The properties of camelina biodiesel and Eurodiesel fuel blends obtained are given in Table 3.

\subsection{Vehicle Tests}

Before performing the experiment, the measurement equipment must be calibrated and the necessary maintenance and installation of the test vehicle has been brought to the values in the catalog and made ready for the experiment. In all experiments, before starting the measurement process, the vehicle engine and the test equipment connected to the vehicle must be run and the vehicle engine must reach its operating temperature. In the experiment, engine power and exhaust emissions were measured in fourth gear and at different vehicle speeds in accordance with the DIN 70200 standard.

The wheels of the vehicle are brought on the chassis dynamometer drums. The vehicle is fastened to the drums on the dynamometer with lashing belts. After the connection belts are passed in a suitable place on the lower swing, they are tied to the drum and the gap of the belts is removed. The clearance process is very important in terms of safety because the vehicle does not move left and right at high speeds. The measurement is started by starting the vehicle. Measurements are calculated by the computer using the formulas below.

\subsection{Engine Power Calculation}

The braked power refers to the shaft power of the engine and is defined by $\mathrm{P}_{\mathrm{e}}$. Shaft power is 
the net or gross power obtained from the engine according to power standards. In comparing engines, this is the most important basis for comparison. The braked power can be measured with a dynamometer that loads the output shaft of the engine. The shaft power of the engine can thus be calculated by the formula below.

$P_{e}=M * \omega$

If the angular velocity of the shaft is unknown, the engine power can also be calculated using the rotational speed.

$P_{e}=M * 2 * \pi * n$

Explanations of the formulas;

$\mathrm{P}_{\mathrm{e}} \quad$ Shaft power $(\mathrm{Nm} / \mathrm{s}=\mathrm{W})$

$\mathrm{M}$ Moment (Nm)

$\omega \quad$ Angular velocity of the shaft ( $\mathrm{rad} / \mathrm{s})$

$\mathrm{n} \quad$ Rotations of rotation $(1 / \mathrm{s})$

\subsection{Engine Torque Calculation}

The engine torque is defined by $\mathrm{M}$ and its SI unit is Newton meters or Nm. Moment defines the density of the combustion pressure created in the cylinder and its transmission to the crankshaft. Moment can be measured using the formula below.

$M=F * r=P / \omega$

or as a numerical value, moment

$M=9550 * P / n$

Explanations of the previous formulas:

$\begin{array}{ll}\text { M } & \text { Moment }(\mathrm{Nm}) \\ \mathrm{F} & \text { Force }(\mathrm{N}) \\ \mathrm{P} & \text { Power }(\mathrm{kW}) \\ \mathrm{r} & \text { Radius }(\mathrm{m}) \\ \omega & \text { Angular velocity }(\mathrm{rad} / \mathrm{s}) \\ \mathrm{n} & \text { Speed }\left(\mathrm{min}^{-1}\right)\end{array}$

\section{Result and Discussion}

The vehicle was brought to full throttle in fourth gear by the operator. Maximum engine speed was $6500 \mathrm{rpm}$ and speed indicator was as 160 $\mathrm{km} / \mathrm{h}$. When the message "Press the clutch pedal" was seen on the computer monitor, the clutch was pressed by the operator and the wheels were waited to stop by themselves. During deceleration, the brake should not be applied.

Figure 2 shows the engine power changes depending on the vehicle speed of the test engine in the use of camelina sativa biodieselEurodiesel fuel blends. Maximum engine power values obtained for Eurodiesel, $\mathrm{B}_{7}, \mathrm{~B}_{20}, \mathrm{~B}_{50}$ and $\mathrm{B}_{100}$ fuels were calculated as 99,6, 101,4, 101,2, 97,7 and 94,3 kW, respectively. Maximum engine power was measured as $101,4 \mathrm{~kW}$ at 160 $\mathrm{km} / \mathrm{h}$ for $B_{7}$ fuel. It is thought that the decrease in engine power depending on the proportion of camelina sativa biodiesel in fuels may result from high density and viscosity of camelina biodiesel.

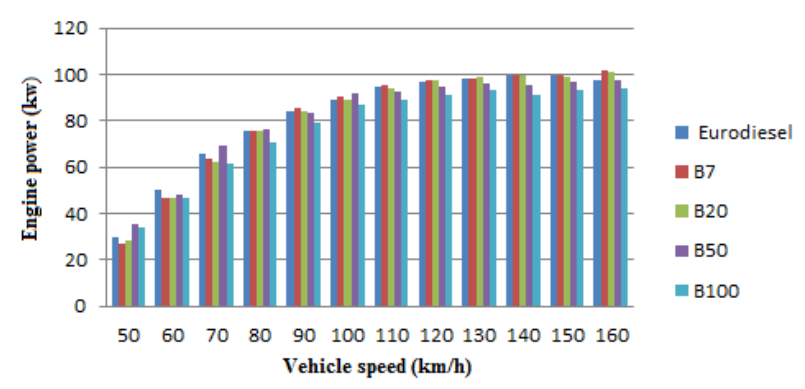

Figure 2.Engine torque change of fuels depending on vehicle speed.

The following equation is used for the uncertainty analysis of engine power in Eurodiesel.

$$
\begin{gathered}
w_{R}=\left[\left(\frac{\partial_{R}}{\partial m} \cdot w_{m}\right)^{2}+\left(\frac{\partial R}{\partial n} \cdot w_{n}\right)^{2}\right]^{\frac{1}{2}} \\
w_{R}=\left[\left(2 * \pi * \mathrm{n} * w_{m}\right)^{2}\right. \\
\left.+\left(\mathrm{M} * 2 * \pi * w_{n}\right)^{2}\right]^{\frac{1}{2}}
\end{gathered}
$$

In the Eurodiesel measurement results, it was seen that $\mathrm{M}=99,6 \mathrm{~kW}, \mathrm{n}=4924 \mathrm{rpm}$ and error rates were $3 \%$ from the catalog $\left(\mathrm{w}_{\mathrm{m}}=\mathrm{w}_{\mathrm{n}}\right)$. When these values are inserted in the formula, the following results are obtained.

$P_{e}=M * 2 * \pi * n=99.60 * 2 * \pi * 4924$

$P_{e}=3081465.083 \mathrm{~W}$

$W_{R}=92.83= \pm \% 3$ value has been found.

Figure 3 shows the change of engine torques for different fuels depending on the vehicle speed. Maximum engine torque values obtained for Eurodiesel, $\mathrm{B}_{7}, \mathrm{~B}_{20}, \mathrm{~B}_{50}$ and $\mathrm{B}_{100}$ fuels were calculated as 274, 277,274, 265 and $253 \mathrm{Nm}$, respectively. Considering the experimental results, the highest torque value among all fuels was obtained in $B_{7}$ fuel at $80 \mathrm{~km} / \mathrm{h}$.

In the tests, the use of Eurodiesel fuel in terms of engine torque gave higher results than $\mathrm{B}_{7}$, $\mathrm{B}_{20}, \mathrm{~B}_{50}$ and $\mathrm{B}_{100}$ fuels. With the increasing percentage of biodiesel in the mixture, the 
torque values decreased. The fact that the torque values are lower results from the lower thermal value and high viscosity of biodiesel compared to Eurodiesel fuel. When the engine torque values are examined, it is seen that the study performed by $[26,27]$ is similar to the engine torque values.

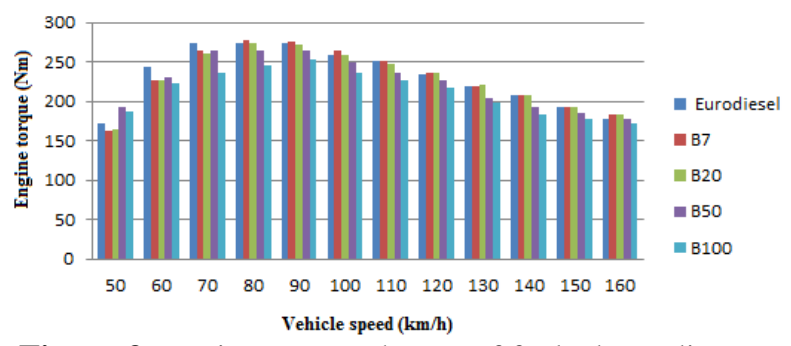

Figure 3. Engine torque change of fuels depending on vehicle speed.

Specific fuel consumption is expressed as the amount of fuel consumed per unit power. Figure 4 shows the effect of using biodiesel on specific fuel consumption. The minimum specific fuel consumption values obtained for Eurodiesel, $\mathrm{B}_{7}$, $\mathrm{B}_{20}, \mathrm{~B}_{50}$ and $\mathrm{B}_{100}$ fuels were calculated as 57,63, $58,9,64,4,72,9$ and $82,4 \mathrm{~g} / \mathrm{kWh}$, respectively. In the tests, the lowest specific fuel consumption values for all fuels were obtained at a vehicle speed of $120 \mathrm{~km} / \mathrm{h}$ with Eurodiesel, $\mathrm{B}_{7}$ and $\mathrm{B}_{100}$ fuels, but it was obtained at a vehicle speed of $100 \mathrm{~km} / \mathrm{h}$ with $B_{20}$ and $B_{50}$ fuels. In general, specific fuel consumption has increased with the use of biodiesel. Specific fuel consumption increases with the increase in the amount of biodiesel in fuels.

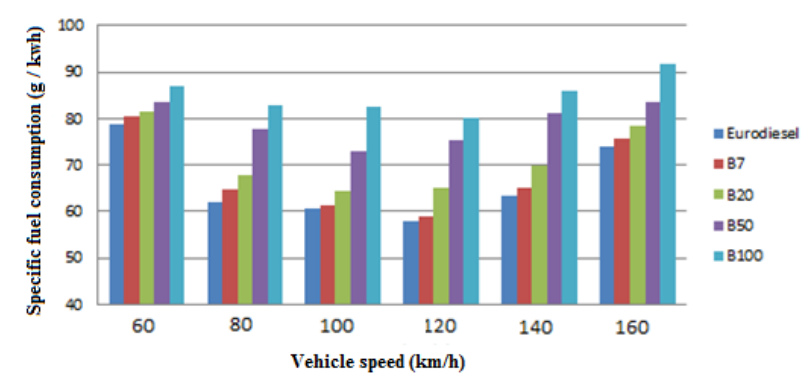

Figure 4. Specific fuel consumption variation depending on vehicle speed

When the fuel mixture is rich (e.g. starting or acceleration), $\mathrm{CO}$ emissions in the engine reach the highest level. Basically, CO formation depends on the excess air coefficient. $\mathrm{CO}$ emissions are one of the important parameters as they represent chemical energy loss that cannot be used in the engine [28-30]. Figure 5 shows how the $\mathrm{CO}$ value in the exhaust gas changes according to the vehicle speed when biodiesel-
Eurodiesel fuel mixture and Eurodiesel are used. According to the experimental results, the lowest $\mathrm{CO}$ emission value for each fuel was determined at a vehicle speed of $160 \mathrm{~km} / \mathrm{h}$. It has been observed that as vehicle speed increases, the air and fuel mixture is improved with better combustion effect and carbon dioxide emissions decrease.

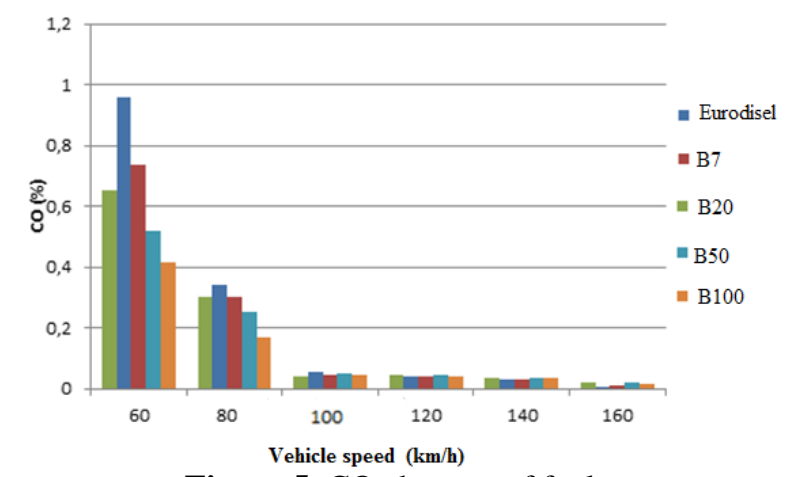

Figure 5. CO changes of fuels

Plants are living things that can capture $\mathrm{CO}_{2}$ produced by burning renewable energy fuels. Plants convert $\mathrm{CO}_{2}$ into carbon and oxygen. Thus, oxygen is released back to the atmosphere [31-33]. Therefore, the use of renewable energy provides a natural balance of $\mathrm{CO}_{2}$ emissions. $\mathrm{CO}_{2}$ in exhaust products is an important parameter as it represents complete combustion. Figure 6 shows the percentage of carbon dioxide as a function of vehicle speed. As it is seen in Figure 6, the $\mathrm{CO}_{2}$ emission values measured during the experiment started to decrease as the biodiesel rate and vehicle speed increased. The highest $\mathrm{CO}_{2}$ emission value was measured as $6,62 \%$. in Eurodiesel fuel at a vehicle speed of $100 \mathrm{~km} / \mathrm{h}$. The lowest was $4,21 \%$ in $\mathrm{B}_{100}$ fuel at a vehicle speed of $160 \mathrm{~km} / \mathrm{h}$.

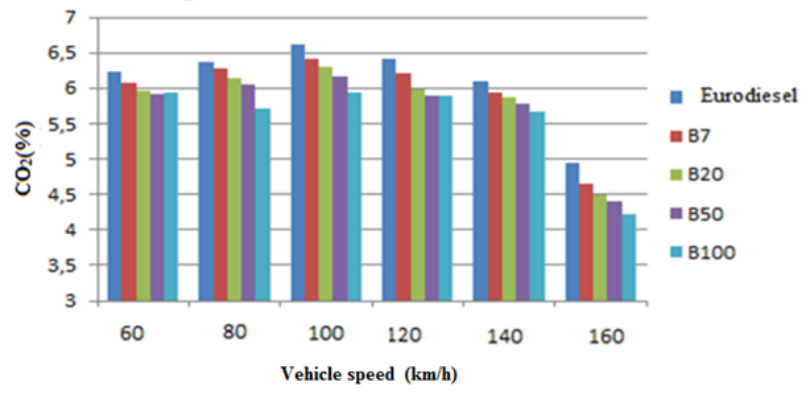

Figure 6. $\mathrm{CO}_{2}$ changes of fuels

A high amount of $\mathrm{O}_{2}$ in the exhaust indicates a poor mixing ratio. As the mixture gets poorer in Eurodiesel engines, fuel consumption decreases and other harmful emissions except $\mathrm{NO}_{\mathrm{x}}$ also decrease.

High $\mathrm{O}_{2}$ content in the exhaust gas indicates a 
poor mixing ratio. As the mixtures in the Eurodiesel engine become poor, fuel consumption decreases and other harmful emissions apart from $\mathrm{NO}_{\mathrm{x}}$ also decrease [34]. Figure 7 shows the amount of $\mathrm{O}_{2}$ in the exhaust gas when biodiesel-Eurodiesel fuel mixture is used. The highest measured $\mathrm{O}_{2}$ emission value was $16,72 \%$ in B100 fuel at a vehicle speed of $160 \mathrm{~km} / \mathrm{h}$. The lowest is $10,15 \%$ in Eurodiesel fuel at $60 \mathrm{~km} / \mathrm{h}$ vehicle speed.

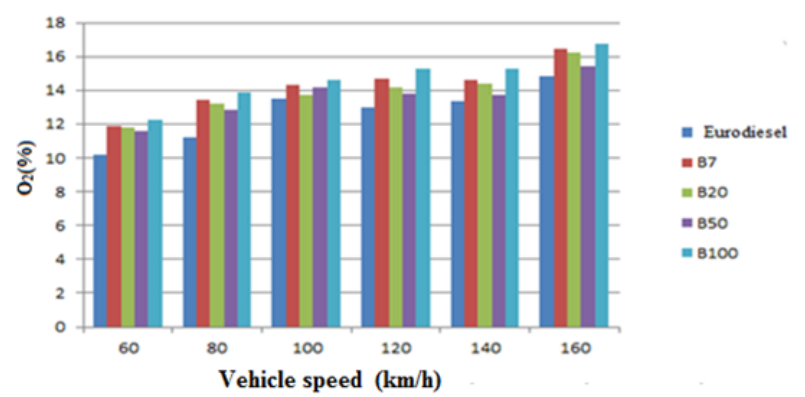

Figure 7. $\mathrm{O}_{2}$ changes of fuels

The reason for the presence of unburned $\mathrm{HC}$ in combustion products is that the fuel cannot reach the ignition temperature, the oxygen is low or the fuel cannot be burned because the fuel cannot find sufficient burning time. Hence, HC refers to unburned fuel [35].

Figure 8 shows the change in $\mathrm{HC}$ value when biodiesel-Eurodiesel mixed fuel is used at different engine speeds. The highest $\mathrm{HC}$ values were measured as 19,29 ppm at $160 \mathrm{~km} / \mathrm{h}$ when Eurodiesel fuel was used. The lowest measured $\mathrm{HC}$ value was found as $7,5 \mathrm{ppm}$ at $80 \mathrm{~km} / \mathrm{h}$ for $\mathrm{B}_{100}$ fuel.

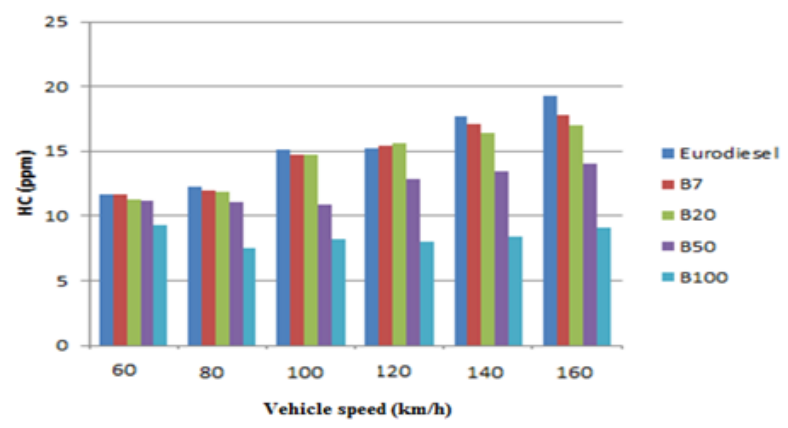

Figure 8. HC changes of fuels

$\mathrm{NO}_{\mathrm{x}}$ is a general term given to emissions such as $\mathrm{NO}$ and $\mathrm{NO}_{2} . \mathrm{NO}_{\mathrm{x}}$ emissions are significantly related to the temperature inside the cylinder, the combustion process, and the amount of oxygen that reacts with it during this reaction. It usually occurs in uncontrolled combustion in places with high temperatures. This is because vegetable oil contains oxygen. The high temperature that occurs after the combustion of fuel in the engine produces nitrogen oxides by combining nitrogen and oxygen in the air. In addition, $\mathrm{NO}_{\mathrm{x}}$ level rises due to prolonged combustion in fast-firing fuel. $\mathrm{NO}_{\mathrm{x}}$ values are high due to the high oxygen temperature that plant-based fuels contain [34-36].

According to the data in the experimental results, the minimum $\mathrm{NO}_{\mathrm{x}}$ emission values were determined for all fuels at a vehicle speed of 160 $\mathrm{km} / \mathrm{h}$. Since biodiesel fuel contains more oxygen than Eurodiesel fuel and the cylinder temperature rises, the use of biodiesel increases $\mathrm{NO}_{\mathrm{x}}$ content. The highest $\mathrm{NO}_{\mathrm{x}}$ value was measured as $527 \mathrm{ppm}$ at $80 \mathrm{~km} / \mathrm{h}$ in B100 fuel.

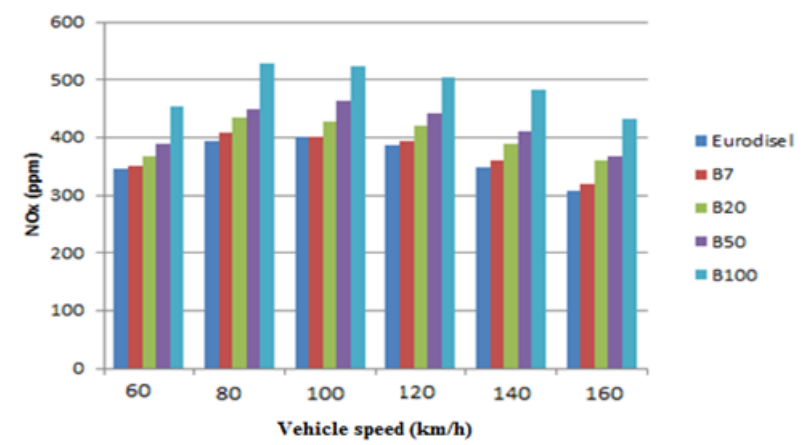

Figure 9. $\mathrm{NO}_{\mathrm{x}}$ changes of fuels

\section{Conclusions}

There are few studies on fuel production from non-renewable plants, especially those that can grow easily on non-arable land, and the demand for irrigation and planting costs is not low.

For this purpose, biodiesel was obtained from Camelina sativa using the transesterification method. Using different ratios of Eurodiesel fuel in a four-cylinder compression ignition engine, the effect of camelina sativa biodiesel on engine performance and emission values was studied. The following results can be obtained by comparing the obtained results with the data from standard Eurodiesel.

As a result, we can say that the reason for the increase of engine power in $\mathrm{B}_{50}, \mathrm{~B}_{20}$ and $\mathrm{B}_{7}$ fuel mixtures compared to Eurodiesel fuel is that the oxygen content in biodiesel contributes to complete combustion. Since biodiesel with high cetane number shortens the ignition delay, a lower combustion temperature is achieved by reducing the amount of fuel in the precombustion stage.

Considering the emission values; $\mathrm{CO}, \mathrm{CO}_{2}$ and $\mathrm{HC}$ emission values decreased as the biodiesel 
ratio and vehicle speed increased, but $\mathrm{NO}_{\mathrm{x}}$ values increased. In terms of the importance of the country's economy, it is important to increase plant-based biodiesel fuel varieties and to grow plants for the production of biodiesel in the suitable areas where there is no plant growing process. In this way, this can contribute to the country and humanity. As a result, using biodiesel obtained from waste oil and vegetable oil as an alternative fuel in Eurodiesel vehicles can positively affect engine performance. Therefore, biodiesel especially reduces exhaust emissions. It reduces greenhouse gases that cause global warming by the use of biodiesel and gases that deplete the ozone layer in the atmosphere.

\section{Acknowledgment}

This research was supported by Selçuk University Scientific Research Projects Coordination Unit with project number 20201022.

\section{References}

1. Hotti, S. and O. Hebbal, Biodiesel production and fuel properties from non-edible Champaca (Michelia champaca) seed oil for use in diesel engine. Journal of Thermal Engineering, 1(1): p. 330-336, 2015.

2. Hill, J., et al., Environmental, economic, and energetic costs and benefits of biodiesel and ethanol biofuels. Proceedings of the National Academy of sciences, 103(30): p. 11206-11210, 2006.

3. Aktaş, A. and Ö. Şahin, Dizel/biyodizel karışımı ile çalışan bir motorun performans ve emisyonlarını iyileştirmek için hidrojen kullanılmasi. Uludağ University Journal of The Faculty of Engineering, 14(1), 2009.

4. Eyidoğan, M., et al., Etanol-Benzin Ve Metanol-Benzin Karışımlarının Buji İle Ateşlemeli Bir Motorun Yanma Parametrelerine Ve Egzoz Emisyonlarına Etkisinin İncelenmesi. Gazi Üniversitesi Mühendislik-Mimarlık Fakültesi Dergisi, 26(3), 2011.

5. Örs, İ., Benzin-etanol karışımlarının taşıt performansına ve egzoz emisyonlarına etkisi, in Fen Bilimleri Enstitüsü. Selçuk Üniversitesi p. 72, 2007.

6. Costagliola, M.A., et al., Performances and emissions of a 4-stroke motorcycle fuelled with ethanol/gasoline blends. Fuel, 183: p. 470-
477, 2016.

7. Peterson, C., et al., The effect of biodiesel feedstock on regulated emissions in chassis dynamometer tests of a pickup truck. Transactions of the ASAE, 43(6): p. 1371, 2000. 8. Bannister, C.D., et al., The impact of biodiesel blend ratio on vehicle performance and emissions. Proceedings of the Institution of Mechanical Engineers, Part D: Journal of Automobile Engineering, 224(3): p. 405-421, 2010.

9. Burke, R.D., et al., A novel use of multivariate statistics to diagnose test-to-test variation in complex measurement systems. Measurement, 130: p. 467-481, 2018.

10. Anne, E.M., Renewable Energy: Sources and Methods. Infobase Publishing, 2009.

11. Acharjee, T.C., Exploring the Potential Use of Camelina sativa as a Biofuel crop for Nevada. 2011.

12. Verduzco, L.F.R., Density and viscosity of biodiesel as a function of temperature: Empirical models. Renewable and Sustainable Energy Reviews, 19: p. 652-665, 2013.

13. Anonim2. Türkiye. TC. Enerji ve Tabii Kaynaklar Bakanlığı [cited $2020 \quad 10$ Eylül 2020]; Available from: http://www.enerji.gov.tr/index.php, 2020.

14. Subramanian, K., et al., Comparative evaluation of emission and fuel economy of an automotive spark ignition vehicle fuelled with methane enriched biogas and $\mathrm{CNG}$ using chassis dynamometer. Applied Energy, 105: p. 17-29, 2013.

15. Anonim1. What is Biodiesel. [cited 2020 24 eylül 2020]; Available from: http://www.esru.strath.ac.uk/EandE/Web_sites/ 02-03/biofuels/what_biodiesel.htm, 2020.

16. Çengelci, E., H. Bayrakçeken, and F. Aksoy, Hayvansal ve bitkisel yağlardan elde edilen biyodizelin dizel yakıtı ile karşılaştırılması. Electronic Journal of Vehicle Technologies (EJVT), 3(1): p. 41-53, 2011.

17. Akay, H. and H. Aydoğan, Ketencik etil esterinin turbo şarjlı bir motorda yakıt olarak kullanımında motorun egzoz emisyonlarına etkisinin araştırılması. Uluslararası Yakıtlar Yanma ve Yangin Dergisi, (4): p. 55-59.

18. Altun, Ş. and C. Öner, Gaseous emission comparison of a compression-ignition engine fueled with different biodiesels. International 
Journal of Environmental Science and Technology, 10(2): p. 371-376, 2013.

19. Aufhammer, W., Getreide-und andere Kornerfruchtarten, Ulmer, 1998.

20. anonymous. Toyota Verso. [cited 2021 13.01.2021]; Available from: https://www.ultimatespecs.com/carspecs/Toyota/13941/Toyota-Verso-Advance20-D-4D-7-seats.html, 2021.

21. Talibi, M., et al., Comparative analysis of H2-diesel co-combustion in a single cylinder engine and a chassis dynamometer vehicle. international journal of hydrogen energy, 44(2): p. 1239-1252, 2019.

22. Anonim. bosch [cited 2020 03.09.2020]; Available from: https://ekilavuz.com/boschbea-350-ekzoz-emisyon-analiz-cihazi-cc3b173f6f3fd090-1, 2020.

23. Özçelik, A.E., H. Aydoğan, and M. Acaroğlu, A study of the effects of bioethanolgasoline blends on vehicle emissions. J. Clean Energy Technol, 3: p. 332-335, 2015.

24. Öğüt, $H$. and H. Oğuz, Üçüncü milenyumun yakıtı biyodizel. Nobel Yayın, (745), 2006.

25. Eryılmaz, T., Hardal yağı biyodizelinde farklı karıșım oranlarının dizel motorlarda performansa etkisi. Selçuk Üniversitesi Fen Bilimleri Enstitüsü, 2009.

26. Nergiz, M., Mp1 enjeksiyon sistemli araçlarda lpg ve benzin kullanımının taşıt performansına etkisinin araştırılması, in Fen Bilimleri Enstitüsü. Afyon Kocatepe Üniversitesi. p. 54, 2008.

27. Chen, L., et al., Using a chassis dynamometer to determine the influencing factors for the emissions of Euro VI vehicles. Transportation Research Part D: Transport and Environment, 65: p. 564-573, 2018.

28. Robles-Medina, A., et al., Biocatalysis: towards ever greener biodiesel production. Biotechnology advances, 27(4): p. 398-408, 2009.

29. Srivastava, A. and R. Prasad, Triglycerides-based diesel fuels. Renewable and sustainable energy reviews, 4(2): p. 111-133, 2000.

30. Ghamkhar, K., et al., Camelina (Camelina sativa (L.) Crantz) as an alternative oilseed: molecular and ecogeographic analyses. Genome, 53(7): p. 558-567, 2010.

31. Ölçüm, T., Biyodizel teknolojisi. 2006.
32. Van Gerpen, J., et al., Biodiesel production technology. National renewable energy laboratory, 1617: p. 80401-3393, 2004.

33. Kiani, S., Bitkisel Yağlardan Biyodizel Üretimde Yüzey Aktif Maddelerin Etkisi, in Fen bilimleri enstitüsü. Shahid Beheshti Üniversitesi. p. 103. 2014.

34. Nişancı, S., Biyodizel yakıt karışımlarının performans ve emisyon üzerine etkilerinin deneysel araştırılması, in Fen Bilimleri Enstitüsü. Yıldız Teknik Üniversitesi. p. 75, 2007.

35. Zhu, L., et al., Emissions characteristics of a diesel engine operating on biodiesel and biodiesel blended with ethanol and methanol. Science of the Total Environment, 408(4): p. 914-921, 2010.

36. Şimşek, R. and H. Aydoğan, Ketencik biyodizelinin üretimi ve common rail enjeksiyon sistemli bir motorun emisyonlarina etkisi. Uluslararas1 Yakıtlar Yanma Ve Yangin Dergisi, (4): p. 60-64, 2016. 